\title{
Does Actual Taxable Income Contain Valuable Information For Shareholders? Evidence From Finland
}

\author{
Erkki K. Laitinen \\ Professor Emeritus*, Unit of Accounting \& Finance \\ Faculty of Business Studies, University of Vaasa \\ Teija Laitinen \\ Professor, Unit of Accounting \& Finance \\ Faculty of Business Studies, University of Vaasa
}

\begin{abstract}
There is much discussion about usefulness of book-tax differences in evaluating firm performance. This study contributes to this discussion assessing the information content of estimated and actual taxable income for Finnish corporate data from 20122013. The findings for year 2012 show that book income has higher explanation power of stock returns than other income concepts. However, estimated taxable income does not bring any incremental explanatory power to book income whereas actual taxable income contains more relative and also incremental information. The findings show that the explanation power of estimated taxable income in high earnings quality firms is comparable with that of book income but insignificant in low earnings quality firms. On the contrary, the explanation power of actual taxable income is lower in high earnings quality firms and higher in low earnings quality firms. For high earnings quality firms, neither of the taxable income concepts brings incremental information to book income. For low earnings quality firms, estimated taxable income does not bring any incremental information to book income whereas actual taxable income does. For these firms, actual taxable income brings significant incremental information also to estimated taxable income. For year 2013, anticipated significant tax rate reduction largely mitigated the relevant relationships between returns and income concepts.
\end{abstract}

Keywords: Estimated taxable income; actual taxable income; pre-tax book income; Helsinki Stock Exchange; stock returns

JEL classification: G Financial Economics; G1 General Financial Markets; G10 General; M Business Administration and Business Economics, Marketing, Accounting \& Personnel Economics; M4 Accounting and Auditing; M40 General; M41 Accounting; H Public Economics; H2 Taxation, Subsidies, and Revenue; H25 Business Taxes and Subsidies

\section{ACKNOWLEDGEMENTS}

The authors are grateful to M.Sc. (Econ.) Anna Lampela for helping in gathering the tax data for the study.

Does actual taxable income contain valuable information for shareholders? Evidence from Finland

\section{INTRODUCTION}

Empirical studies on taxation suggest that book-tax differences are useful measures in evaluating firm performance (Hanlon, 2005; Lev \& Nissim, 2004; Ayers, Jiang \& Laplante, 2009; Hanlon \& Heitzman, 2010). Shevlin (2002) and Hanlon, Laplante \& Shevlin (2005) report that book income explains annual stock returns better than estimated taxable income that is calculated using financial statement disclosures. However, they also report that this estimated 
taxable income brings incremental explanatory power to book income indicating that taxable income summarizes information reflected in stock returns that is not captured by book income. Ayers, Jiang \& Laplante (2009) show that the relative and incremental information content of estimated taxable income to book income is lower for high tax planning firms and higher for low earnings quality firms. However, there are still limited studies considering taxable income as an alternative performance measure. Especially, there is very little research on the information content of actual taxable income due to the difficult access to corporate tax information that is almost always not public. In Finland, corporate tax information came public in year 2011 making it possible to use actual tax figures in research. The objective of this research is to contribute to current taxation research assessing the information content of both estimated and actual taxable income using Finnish corporate data from 2011-2013.

There is an extensive literature on book-tax conformity dealing with the publicity of corporate tax information (Ayers, Jiang \& Laplante, 2009). The supporters of mandatory book-tax conformity argue that the dual system of reporting book and taxable income is an area of creative decision making leading to that the taxable income does not reflect the actual performance of a firm (Desai, 2006: 8). They argue that aggressive tax planning may lead to significant book-tax differences making taxable income unable to reflect performance. Consequently, they argue that firms should either pay tax on the reported financial income or at least should disclose tax information to investors. These arguments have been an object for keen discussion by regulators, practitioners, and academics (Hanlon \& Shevlin, 2003; Mills \& Plesko, 2003). However, there is plenty of evidence suggesting that taxable income may reflect performance, especially for firms with lower earnings quality (Revsine, Collins \& Johnson, 2002; Lev \& Nissim, 2004; Hanlon, 2005; Ayers, Jiang \& Laplante, 2009). Therefore, taxable income may be a useful measure of income when book income suffers from low quality of earnings.

There is only little evidence on relation between estimated taxable income and actual taxable income. Plesko (2000) and Plesko (2006) report that while commonly used average tax rate may introduce substantial bias into analyses of tax incidence, taxable income estimated from financial statement is highly correlated with actual taxable income indicating that estimated taxable income is a satisfactory proxy for actual taxable income. However, it is still an unanswered question whether actual taxable income contains useful relative and incremental information for investors to book income and estimated taxable income when the quality of financial statement information is low. The purpose of this study is to bring evidence of the potential relative and incremental information contained by estimated and actual taxable income to book income when explaining return to security for 100 Finnish firms traded in Helsinki Stock Exchange (Nasdaq Nordic) in year 2012 and 2013.

For year 2012, evidence shows that book income has higher explanation power of stock returns than other income concepts. However, estimated taxable income does not bring any incremental explanatory power to book income whereas actual taxable income contains more relative and incremental information. The explanation power of estimated taxable income in high earnings quality firms is comparable with that of book income but insignificant in low earnings quality firms. On the contrary, the explanation power of actual taxable income is lower in high earnings quality firms and higher in low earnings quality firms. For high earnings quality firms, neither of the taxable income concepts brings incremental information to book income. For low earnings quality firms, estimated taxable income does not bring any incremental information to book income whereas actual taxable income does. For these firms, 
actual taxable income brings significant incremental information also to estimated taxable income.

The study is organized in the following way. First, the background, the motivation, and the objective of the study are discussed in this introductory section. The second section shortly presents the framework for the analysis and discusses the information content of taxable income concepts. In this section, also the research hypotheses (for the information content in general and in low information quality firms) are extracted. The third section presents the data and statistical methods of the study. The study makes use of a similar approach than Ayers, Jiang \& Laplante (2009) in assessing the relative and incremental information content of the tax concepts. The data are gathered from 100 public firms traded in the Helsinki Stock Exchange (HSE) from the Orbis data base of Bureau Van Dijk (BvD) (financial information) and from the tax authority (actual taxable income and taxes). Corporate tax information is public only in a couple of countries (Japan, Norway, Sweden, and Finland). Finland has the most robust corporate tax disclosure making available information on taxable income, capital income and total taxes payable which makes the study unique. The fourth section reports the empirical findings while the last section discusses these findings and concludes the study.

\section{General hypotheses on the income concepts}

\section{EXTRACTION OF RESEARCH HYPOTHESES}

Managers use book and tax income reporting for different purposes although these concepts can be related to each other. If financial performance is excellent, managers may report lower book income for political cost purposes or to increase possibilities to report also lower tax income to minimize taxes. If financial performance is not good, managers may have incentives to report higher book income for example due to bond covenants or compensation contracts. However, at the same time they can have motivation to report lower taxable income for tax purposes. Because managers have different incentives in reporting book and taxable income which both serve as a summary performance measure based on the set of rules of their own, each measure may include important information for the stakeholders of the firm (tax authorities and the users of financial statement analysis). These measures should be informative if the shocks to taxable income and book and their managed components are not identical (Lev \& Nissim, 2004; Ayers, Jiang \& Laplante, 2009). If the shocks are identical, they do not contain incremental information over each other. Thus, the relevant question from the perspective of this study is whether taxable income concepts contain this kind of incremental information reflecting stock returns and being therefore useful for the shareholders of the firm.

Hanlon (2005) and Lev and Nissim (2004) show that book-tax differences are useful measures in evaluating firm performance (earnings growth, future stock returns, and earnings persistence). Shevlin (2002) and Hanlon, Laplante, and Shevlin (2005), and Ayers, Jiang \& Laplante (2009) find that while book income better explains annual stock returns than taxable income (estimated using financial statement disclosures), estimated taxable income has significant incremental explanatory power to book income. In practice, there are several problems in estimating tax liability for a firm and consequently taxable income from financial statements (Hanlon, 2003). These problems may weaken the relationship between the estimated taxable income and the actual taxable income. Plesko (2000) and Plesko (2006) report that the commonly used average tax rate may introduce substantial bias into analyses of tax incidence. However, taxable income estimated from financial statement is highly correlated with actual taxable income indicating that estimated taxable income is a satisfactory proxy for actual taxable income. This kind of close relationship can lead to similar findings for estimated and actual taxable income concepts. Therefore, the following general research hypotheses are presented: 
Hypothesis 1a: Estimated taxable income has incremental explanatory power to book income. Hypothesis 1b: Actual taxable income has incremental explanatory power to book income.

Hypothesis 2a: Actual taxable income does not have incremental explanatory power to estimated taxable income.

Hypothesis 2b: Estimated taxable income and actual taxable income have equal relative explanatory power to estimated taxable income.

\section{Hypotheses on the effects of low information quality}

The information content of estimated taxable income and actual taxable income may depend on the quality of earnings information. If deferred tax liability increases, it can indicate deteriorating information quality (Revsine, Collins \& Johnson, 2002). The effects of low information quality on the information content of taxable income concepts depend on the source of lower earnings quality and the similarity of the effects (shocks) on book income and taxable income. If the low quality comes from transitory events (being value relevant with low persistence) reflected in book income but not in taxable income, then the relative ability of current year taxable income to explain returns can actually decrease. Thus, it is an empirical question whether taxable income enhances information content when earnings quality is lower (Ayers, Jiang \& Laplante, 2009).

Hanlon, Laplante \& Shevlin (2005) and Ayers, Jiang \& Laplante (2009) find that book income explains annual stock returns better than the taxable profit, on average, and for firms with large abnormal accruals. Ayers, Jiang \& Laplante (2009) find that the relative information content of estimated taxable income to book income for firms with large abnormal accruals is significantly larger compared to other firms. However, they report that the incremental information content of taxable income, on average, is moderate. Their conclusions from incremental information content tests for firms with lower information quality are similar than for the relative information content but the incremental information content of taxable income is quite modest. Thus, the following hypotheses are presented on the effect of information quality:

Hypothesis 3a: Estimated taxable income has higher relative explanatory power to book income for firms with lower earnings quality.

Hypothesis $3 \boldsymbol{b}$ : Actual taxable income has higher relative explanatory power to book income for firms with lower earnings quality.

Hypothesis 4a: Estimated taxable income has higher incremental explanatory power to book income for firms with lower earnings quality.

Hypothesis 4b: Actual taxable income has higher incremental explanatory power to book income for firms with lower earnings quality.

Hypothesis 4c: Actual taxable income does not have higher incremental explanatory to estimated taxable income for firms with lower earnings quality.

\section{Empirical data}

\section{DATA AND STATISTICAL METHODS}

The data of the study consists of firms which are traded in the Helsinki Stock Exchange (HSE) during the years 2011-2014. HSE was founded in 1912 as a nonprofit cooperative organization but today it is the part of NASDAQ OMX Exchanges. The number of listed firms in HSE was in the research period at year-end 122-124. The market value of HSE at the end of years 2013 and 2014 was 162 and 168 Billion Euro, respectively. Financial institutions were excluded from the data. Furthermore, all (new and delisted) firms with missing values of the research variables were excluded from the sample. Finally, the sample consisted of 100 listed companies with a skew size distribution. The average size of sample firms $(n=100)$ as measured by total assets 
at end of 2013 was 1683.1 Million Euro whereas the median was only 255.9 Million Euro. The data were gathered from three sources. Thus, stock price data were got from Kauppalehti (www.kauppalehti.fi), financial statement information from the Orbis data base of Bureau Van Dijk (BvD), and all actual tax data from the tax authority. Corporate income tax information has been publicly released beginning from 2011 making available information on taxable income, capital income and total taxes payable. Finnish companies also disclose reconciliations between book income and tax income.

The research period suffers from a high volatility due to the effects of global financial crisis beginning already in 2008 in Finland. The second contraction started after the financial crisis in the second quarter of 2012 resulting in a period of prolonged recession. In years 2012-2013 Finland's GDP declined by $1.0 \%$ and $1.4 \%$ respectively and confidence indicators fell sharply. The effects of the crisis were visible also in the market values of the firms traded in HSE. The change in Helsinki all-share index (\%) was in years 2011-2014 respectively -30.1, 8.3, 26.5, and 5.7. Consequently, most firms traded at HSE suffered from financial distress during the period. The difficult economic situation has obviously had an influence on the income concepts and their relationships to stock returns, and to each other. In fact, 44 (46) out of 100 firms did not pay any income taxes for 2012 (2013) so that actual taxable income was zero for these firms. Therefore, the statistical tests are made also for the groups with non-zero income tax $(n=56$ or 54) for 2012 and 2013. The volatility of economic conditions in Finland and especially in HSE stock market during the research period should be taken into account when assessing the findings of this study.

The income concepts are defined as in most earlier studies to maintain comparability. Taxable income is in taxation research calculated or estimated in many different ways depending on available information (see Hanlon \& Heitzman, 2010). In this study, estimated taxable income $E T I(j, t)$ for firm $j$ and year $t$ is calculated as follows:

$$
\operatorname{ETI}(j, t)=\frac{C T E(j, t)+D T E(j, t)}{f}
$$

where $C T E(j, t)$ is current income tax expense (payable), DTE(j,t) is deferred income tax expense, and $f$ is the corporate income tax rate in Finland. Book income PTBI(j,t) is calculated here as a pre-tax measure of book income to be consistent with estimated taxable income $E T I(j, t)$. Finally, actual taxable income $A T I(j, t)$ is the income which the actual annual income tax is paid on. The corporate tax rate $(f)$ in Finland has not been stable in years 2011-2014 being respectively $0.26,0.245,0.245,0.20$. The large decrease of tax rate in 2013-2014 was fully known to market participants in Autumn of 2013 which may have affected taxation behavior in that year.

Ayers, Jiang \& Laplante (2009) used abnormal accruals estimated by the modified Jones model to reflect the quality of earnings information although it is subject to criticism (Dechow, Ge \& Schrand, 2010). However, in this study earnings quality is measured by absolute total accruals partly due to exceptionally unstable economic conditions during the research period 20112013. The performance of this measure is based on the expectation that extreme accruals refer to low quality because they represent a less persistent component of earnings. Dechow, Ge \& Schrand (2010) showed that absolute accruals are strongly positively correlated with other accrual measures and negatively with smoothness proxies. When analyzing deferred taxes in detecting earnings management, Phillips, Pincus \& Rego (2003) reported that total accruals is incrementally useful in several settings, while the performance of abnormal accrual measures is mixed. Total accruals (TACC) are in this study calculated in the traditional way as the change 
in current assets, plus the change in short-term debt, less the change in current liabilities, the change in cash, and depreciation and amortization expense. Finally, total accruals are deflated by total assets. Ayers, Jiang \& Laplante (2009) identify firms as low earnings quality by designating firms ranked in the highest $20 \%$ of absolute abnormal accruals as having low earnings quality. However, in this approach firms are in 2012 and 2013 classified in two equal groups using the median $(50 \%)$ as cutoff because of the small number of firms $(n=50+50)$. Ayers, Jiang \& Laplante (2009) identified as low earnings quality firms which were ranked in the highest $20 \%$ of absolute abnormal accruals for each year.

\section{Statistical methods: relative explanatory power}

The statistical methods used in this study have similarities with those adopted by Ayers, Jiang \& Laplante (2009) to ensure comparability of findings. However, the present data include observations of income concepts only from two years (2012 and 2013) which does not allow us to test hypotheses over time. A long-window tests are used for the information content of book income, estimated taxable income, and actual taxable income for all firms in $\mathrm{H} 1-\mathrm{H} 2$ and low earnings quality firms in $\mathrm{H3}-\mathrm{H} 4$ relative to all other firms. As in Ayers, Jiang \& Laplante (2009), information content is defined here as the ability of the income concepts to capture information that affects stock returns. Because the focus of the analysis is set on the ability of the concepts to capture all information that affects stock returns, and not on the causality, a long-window association tests are utilized. The different statistical association tests are used separately to test separately relative and incremental information content of income concepts in explaining stock returns. The present analyses are based on a 23-month long window testing ending 11 months after fiscal year to be sure that market participants have received all annual tax income numbers. In Finland, corporate tax information is released in the beginning of next November when the accounting year ends at the end of the year. The long window based on the long delay in receiving actual tax information obviously weakens the ability of the income concepts to explain returns. Therefore, it is expected that the explanation power will not be high.

Further, following Ayers, Jiang \& Laplante (2009) two different tests are utilized to assess the research hypotheses. The first set of hypotheses on the relative explanatory power of income concepts $(H 2 b, H 3 a$, and $H 3 b)$ are tested as the adjusted $R^{2}$ in regressions of stock returns on each concept. The following three equations are estimated for each group of firms (all firms, zero tax firms, low earnings quality firms, high earnings quality firms):

$$
\begin{aligned}
& \operatorname{rank}(R(j, t))=\alpha_{0}+\alpha_{1} \operatorname{rank}(\triangle P T B I(j, t))+\varepsilon(j, t) \\
& \operatorname{rank}(R(j, t))=\alpha_{0}+\alpha_{1} \operatorname{rank}(\Delta \operatorname{ETI}(j, t))+\varepsilon(j, t) \\
& \operatorname{rank}(R(j, t))=\alpha_{0}+\alpha_{1} \operatorname{rank}(\Delta A T I(j, t))+\varepsilon(j, t)
\end{aligned}
$$

where $R(j, t)$ the return to security $j$ over the 23 -month window (transformed to annual rate) starting at the beginning of fiscal year $t$ and ending eleven months after the end of year $t$. The changes in income concepts $(\triangle P T B I(j, t), \triangle E T I(j, t)$, and $\triangle A T I(j, t)$ ) refer to the annual differences of the measures and are scaled by the market value of equity measured at the start of fiscal year $t$. The specification (2) based on changes of income concepts is used to mitigate concerns associated with levels regressions like omitted variables and heteroscedasticity (Kothari, 2001; Ayers, Jiang \& Laplante, 2009). Finally, stock return and income concepts in (2) have transformed to their ranks to control for obvious changes in market volatility (cf. Ali \& Whang, 2000). Therefore, $R^{2}$ in the regressions correspond to the squared Spearman coefficient of 
correlation. This approach does not assume a linear relation between stock returns and income concepts and is useful in avoiding extreme values of variables.

The test statistics used in testing the relative explanatory power $(R E P)$ of income concepts are based on the adjusted $R^{2}$ from equations (2) calculated for each group of firms separately for years 2012 and 2013 in the following way:

$$
\begin{aligned}
& R E P(E T I / P T B I)=\frac{\text { Adjusted } R^{2}(\triangle E T I)}{\text { Adjusted } R^{2}(\triangle P T B I)} \\
& R E P(A T I / P T B I)=\frac{\text { Adjusted } R^{2}(\triangle A T I)}{\text { Adjusted } R^{2}(\triangle P T B I)} \\
& R E P(A T I / E T I)=\frac{\text { Adjusted } R^{2}(\triangle A T I)}{\text { Adjusted } R^{2}(\Delta E T I)}
\end{aligned}
$$

The relative power indices REP are calculated separately for years 2012 and 2013 to assess the effect of high volatility in the market. The indices are useful when allowing us to compare the information content of two income concepts holding returns for the firm constant (Ayers, Jiang \& Laplante, 2009). For $H 2 b$, it is expected that $R E P(E T I / P T B I)$ is equal to $R E P(A T I / P T B I)$. It also implies that $R E P(A T I / E T I)$ is equal to unity. For $H 3 a$ and $H 3 b$, it is predicted that respectively $R E P(E T I / P T B I)$ and $R E P(A T I / P T B I)$ are higher for firms with lower earnings quality. Furthermore, the equality of rank correlations of return to $\triangle E T I$ and $\triangle A T I$ in the same sample is evaluated by $t$-test for comparing two non-independent correlations with one variable in common (Williams, 1959) and in different sub-samples using the $z$-test based on the Fisher $r$ to-z transformation (Cohen \& Cohen, 1983).

\section{Statistical methods: incremental explanatory power}

The second set of hypotheses on the incremental explanatory power of income concepts (H1a, $H 1 b, H 2 a, H 4 a$, and $H 4 b$ ) are also tested as the adjusted $R^{2}$ in regressions of stock returns. However, in these tests the incremental explanatory power of including another income concept in a regression of an income concept on stock returns is assessed. The following three regression equations are estimated for each group of firms (all firms, zero tax firms, low earnings quality firms, high earnings quality firms):

$$
\begin{aligned}
& \operatorname{rank}(R(j, t))=\beta_{0}+\beta_{1} \operatorname{rank}(\Delta P T B I(j, t))+\beta_{2} \operatorname{rank}(\Delta E T I(j, t))+\varepsilon(j, t) \\
& \operatorname{rank}(R(j, t))=\beta_{0}+\beta_{1} \operatorname{rank}(\Delta P T B I(j, t))+\beta_{2} \operatorname{rank}(\Delta A T I(j, t))+\varepsilon(j, t) \\
& \operatorname{rank}(R(j, t))=\beta_{0}+\beta_{1} \operatorname{rank}(\Delta E T I(j, t))+\beta_{2} \operatorname{rank}(\Delta A T I(j, t))+\varepsilon(j, t)
\end{aligned}
$$

where all concepts are defined as earlier.

The incremental explanatory power (IEP) of income concepts is tested by the difference between the adjusted $R^{2}$ from equation (2) and the adjusted $R^{2}$ from equation (4) for the concepts in question. Thus, the incremental explanatory is measured by the following differences:

$$
\begin{aligned}
& I E P(P T B I+E T I)=\text { Adjusted } R^{2}(\triangle P T B I+\triangle E T I)-\text { Adjusted } R^{2}(\triangle P T B I) \\
& I E P(P T B I+A T I)=\text { Adjusted } R^{2}(\triangle P T B I+\triangle A T I)-\text { Adjusted } R^{2}(\triangle P T B I) \\
& I E P(E T I+A T I)=\text { Adjusted } R^{2}(\triangle E T I+\triangle A T I)-\text { Adjusted } R^{2}(\Delta E T I)
\end{aligned}
$$

where the former terms in the right hand side of equation refer to the regression equations in (4) whereas the latter terms refer to equation (2). For $H 1 a$ and $H 1 b$, it is expected that $I E P(P T B I+E T I)$ and $I E P(P T B I+A T I)$ respectively are positive. For $H 2 a$, it is predicted that 
$I E P(E T I+A T I)$ equals zero. $H 4 a$ and $H 4 b$ assume that IEP(PTBI+ETI) and IEP(PTBI+ATI) respectively are higher for firms with lower earnings quality whereas $H 4 c$ expects that $I E P(E T I+A T I)$ is equal for both earnings quality groups of firms. The incremental information content is also assessed by the $t$-tests on the coefficients in Equation (4) following the traditional random-walk specification (Biddle, Seow \& Siegel, 1995).

\section{Descriptive statistics}

\section{EMPIRICAL RESULTS}

Table 1 presents descriptive statistics for the research variables for the sample $(n=100)$. The table shows that the average level of absolute accruals (TACC) has stayed stable over 20122013. The distributions of the return variables $(R)$ and the differences in income variables (PTBI, ETI, and ATI) are strongly leptokurtic reflected by a high kurtosis. The return variables $(R)$ follow a highly positively skewed distributions. Thus, the use of the rank variables in the regression equation is well justified due to the strong deviations from normality observed in the research variables. The mean and median values of the differences in pre-tax book income variables $(P T B I)$ are negative reflecting conditions of financial distress. The mean values of the differences in estimated taxable income $(E T I)$ are positive whereas median values are negative. The mean values of the differences in actual taxable income $(A T I)$ are slightly negative but the median values are zero due to the large number of zero tax firms. The absolute differences in pre-tax book income (PTBI) are on average clearly higher than those in estimated taxable income $(E T I)$ and actual taxable income $(A T I)$. The average absolute differences in the actual taxable profit (ATI) are clearly smallest which may be at least partly due to the large number of zero tax firms.

Table 1. Descriptive statistics of the research variables.

\begin{tabular}{|c|c|c|c|c|c|c|}
\hline & Mean & $\begin{array}{l}\text { Std. } \\
\text { Deviation }\end{array}$ & Median & Skewness & Kurtosis & $\begin{array}{l}\text { Number } \\
\text { of firms }\end{array}$ \\
\hline TACC(2012) & 0,076 & 0,110 & 0,044 & 4,029 & 20,185 & 100 \\
\hline $\operatorname{TACC}(2013)$ & 0,083 & 0,107 & 0,044 & 2,412 & 6,110 & 100 \\
\hline$R(2012)$ & 12,494 & 62,209 & 6,250 & 4,751 & 32,416 & 100 \\
\hline$R(2013)$ & 10,526 & 67,532 & 3,275 & 5,731 & 44,189 & 100 \\
\hline$\triangle P T B I(2012)$ & $-3,110$ & 36,501 & $-0,068$ & $-1,818$ & 17,055 & 100 \\
\hline$\triangle P T B I(2013)$ & $-1,982$ & 35,843 & $-1,488$ & $-1,292$ & 13,484 & 100 \\
\hline$\Delta E T I(2012)$ & 0,315 & 24,402 & $-0,013$ & 3,558 & 32,565 & 100 \\
\hline$\Delta E T I(2013)$ & 0,925 & 42,265 & $-0,373$ & $-2,588$ & 30,563 & 100 \\
\hline$\triangle A T I(2012)$ & $-0,260$ & 6,899 & 0,000 & $-1,656$ & 23,609 & 100 \\
\hline$\triangle A T I(2013)$ & $-0,258$ & 3,219 & 0,000 & 0,717 & 12,779 & 100 \\
\hline
\end{tabular}

Legend:

TACC (year) $=$ Total absolute accruals deflated by total assets.

$R($ year $)=$ Stock return over the 23-month return window transformed on annual basis.

$\triangle P T B I$ (year) $=$ Difference in $100 \cdot$ pre-tax book income deflated by market value .

$\triangle E T I$ (year) $=$ Difference in $100 \cdot$ estimated taxable income deflated by market value.

$\triangle A T I($ year $)=$ Difference in $100 \cdot$ actual taxable income deflated by market value.

\section{Relative explanatory power}

Table 2 presents the regression estimates for the relative information content of pre-tax book income, estimated taxable income, and actual taxable income (Equation 2). The table also 
reports the REP measures for each pair of income concepts (Equation 3). The relative explanatory power of pre-tax book income $(P T B I)$ is quite high in both years and significantly higher than that of other concepts. The power is clearly higher for year 2012 than for year 2013. The adjusted $R^{2}$ for the equation of actual taxable income (ATI) is in year 2012 higher than for the estimated taxable income (ETI). However, the power is negative in 2013 for both concepts. Practically, these concepts do not show for year 2013 explanation power at all. Estimated taxable income (ETI) explains $45.9 \%$ of the return variation explained by book income (PTBI) in 2012 whereas the percent is $57.7 \%$ for the actual taxable income (ATI). These results at least slightly contradict with $H 2 b$ on the equality of the relative explanatory power of estimated taxable income (ETI) and actual taxable income (ATI) although the difference in their correlations to return is not statistically significant $(p=0.413)$. For year 2013 , the results are inconclusive due to negative values of $R^{2}$.

Table 2. Relative information content of estimated and actual taxable income to book income for all sample firms.

\begin{tabular}{|c|c|c|c|c|c|c|c|c|c|c|}
\hline Year & $\begin{array}{l}\text { Numb } \\
\text { er of } \\
\text { firms }\end{array}$ & $\begin{array}{l}\text { Coefficien } \\
\text { t of } \\
\text { DPTBI§ }\end{array}$ & $\begin{array}{l}\mathrm{p} \text {-value } \\
\text { of } \\
\text { coefficie } \\
\text { nt }\end{array}$ & $\begin{array}{l}\mathrm{R}^{2}(\triangle \mathrm{PTBI} \\
) \&\end{array}$ & $\begin{array}{l}\text { Coefficient } \\
\text { of } \Delta \mathrm{ETI} \S\end{array}$ & $\begin{array}{l}p \text {-value } \\
\text { of } \\
\text { coefficien } \\
t\end{array}$ & $\begin{array}{l}\mathrm{R}^{2}(\Delta \mathrm{ETI}) \\
\&\end{array}$ & $\begin{array}{l}\text { Coefficient } \\
\text { of } \triangle A T I \S\end{array}$ & $\begin{array}{l}p \text {-value } \\
\text { of } \\
\text { coefficien } \\
t\end{array}$ & $\begin{array}{l}\mathrm{R}^{2}(\Delta \mathrm{ATI}) \\
\&\end{array}$ \\
\hline 2012 & 100 & 0,353 & 0,000 & 0,111 & 0,250 & 0,014 & 0,051 & 0,271 & 0,006 & 0,064 \\
\hline 2013 & 100 & 0,256 & 0,012 & 0,053 & 0,083 & 0,425 & $-0,004$ & 0,047 & 0,650 & $-0,008$ \\
\hline
\end{tabular}

\begin{tabular}{|c|r|r|r|r|}
\hline Year & $\begin{array}{l}\text { Numb } \\
\text { er of } \\
\text { firms }\end{array}$ & $\begin{array}{l}\mathrm{R}^{2}(\Delta \mathrm{ETI}) / \\
\mathrm{R}^{2}(\Delta \mathrm{PTBI})\end{array}$ & $\begin{array}{r}\mathrm{R}^{2}(\Delta \mathrm{ATI}) / \\
\mathrm{R}^{2}(\Delta \mathrm{PTBI})\end{array}$ & $\mathrm{R}^{2}(\Delta \mathrm{ATI}) /$ \\
\hline 2012 & 100 & 0,459 & 0,577 & 1,255 \\
\hline 2013 & 100 & $-0,075$ & $-0,151$ & 2,000 \\
\hline
\end{tabular}

Lege

nd:

$\S=$ Coefficient from a regression of return (rank) on the change (rank) in pre-tax book income, estimated taxable income or actual taxable income (Equation 2 ).

$\&=$ Adjusted $R^{2}$ from a regression of return (rank) on the change (rank) in pre-tax book income, estimated taxable income or actual taxable income (Equation 2).

$\triangle P T B I=$ Difference in $100 \cdot$ pre-tax book income deflated by market value .

$\triangle E T I=$ Difference in $100 \cdot$ estimated taxable income deflated by market value.

$\triangle A T I=$ Difference in $100 \cdot$ actual taxable income deflated by market value.

In years 2012 and 2013, the majority of firms (56 and 54 firms) report zero actual taxable income and do not pay income taxes at all. Table 3 shows the results on the relative explanation power only for the firms which have paid income taxes for these years (non-zero tax firms). For the non-zero tax firms, the explanation power in year 2012 has considerably increased for pre-tax book income (PTBI) and estimated taxable income (ETI) in comparison to all firms. However, for actual taxable income $(A T I)$ the power has to some degree decreased. The relative explanation power (REP) for ETI is $57.7 \%$ but only $22.9 \%$ for $A T I$. Thus, $R E P$ s for $E T I$ and $A T I$ in this sub-sample are not equal which contradicts with $H 2 b$. However, the difference in their (rank) correlations to return is not statistically significant $(p=0.210)$. For this part of sample, all income concepts report negative adjusted $R^{2}$ for 2013 . Therefore, any of the income concepts does not include any explanation power on stock returns in that year. 
Table 3. Relative information content of estimated and actual taxable income to book income for non-zero tax firms.

\begin{tabular}{|c|c|c|c|c|c|c|c|c|c|c|}
\hline Year & $\begin{array}{l}\text { Numbe } \\
r \text { of } \\
\text { firms }\end{array}$ & $\begin{array}{l}\text { Coefficient } \\
\text { of } \triangle \text { PTBI§ }\end{array}$ & $\begin{array}{l}\text { p-value } \\
\text { of } \\
\text { coefficie } \\
n t\end{array}$ & $\begin{array}{l}\mathrm{R}^{2}(\triangle \mathrm{PT} \mathrm{BI}) \\
\&\end{array}$ & $\begin{array}{l}\text { Coefficie } \\
n t \text { of } \\
\Delta \text { ETI§ }\end{array}$ & $\begin{array}{l}\mathrm{p} \text {-value } \\
\text { of } \\
\text { coefficie } \\
\mathrm{nt}\end{array}$ & $\begin{array}{l}\mathrm{R}^{2}(\Delta \mathrm{ETI}) \\
\&\end{array}$ & $\begin{array}{l}\text { Coefficie } \\
\text { nt of } \\
\triangle A T I \S\end{array}$ & $\begin{array}{l}p \text {-value of } \\
\text { coefficien } \\
t\end{array}$ & $\begin{array}{l}\mathrm{R}^{2}(\Delta \mathrm{ATI}) \\
\&\end{array}$ \\
\hline 201 & 56 & 0,476 & 0,000 & 0,201 & 0,374 & 0,006 & 0,116 & 0,258 & 0,062 & 0,046 \\
\hline 2013 & 54 & 0,117 & 0,412 & $-0,006$ & 0,071 & 0,618 & $-0,014$ & $-0,013$ & 0,927 & $-0,019$ \\
\hline
\end{tabular}

\begin{tabular}{|c|c|c|c|c|}
\hline Year & $\begin{array}{l}\text { Numbe } \\
r \text { of } \\
\text { firms }\end{array}$ & $\begin{array}{l}R^{2}(\Delta \mathrm{ETI}) / \\
\mathrm{R}^{2}(\Delta \mathrm{PTBI})\end{array}$ & $\begin{array}{l}\mathrm{R}^{2}(\triangle \mathrm{ATI}) \\
/ \\
\mathrm{R}^{2}(\triangle \mathrm{PTBI} \\
)\end{array}$ & $\begin{array}{l}\mathrm{R}^{2}(\Delta \mathrm{ATII}) / \\
\mathrm{R}^{2}(\Delta \mathrm{ETII})\end{array}$ \\
\hline 2012 & 56 & 0,577 & 0,229 & 0,397 \\
\hline 2013 & 54 & 2,333 & 3,167 & 1,357 \\
\hline
\end{tabular}

Legend

$\S=$ Coefficient from a regression of return (rank) on the change (rank) in pre-tax book income, estimated taxable income or actual taxable income (Equation 2).

$\&=$ Adjusted $R^{2}$ from a regression of return (rank) on the change (rank) in pre-tax book income, estimated taxable income or actual taxable income (Equation 2).

$\triangle P T B I=$ Difference in $100 \cdot$ pre-tax book income deflated by market value.

$\triangle E T I=$ Difference in $100 \cdot$ estimated taxable income deflated by market

value.

$\triangle A T I=$ Difference in $100 \cdot$ actual taxable income deflated by market value.

Table 4 reports the relative explanation power of the income concepts separately for low accruals (50\%) (high earnings information quality) and high accruals (50\%) firms (low earnings information quality). For year 2012, the explanation power of pre-tax book income $(P T B I)$ is quite comparable for low accruals firms and high accruals firms so that the correlations to return do not statistically differ $(p=0.429)$. The explanation power of estimated taxable income (ETI) is for low accruals firms high in 2012 making $91.8 \%$ of that of $P T B I$. However, REP is close to zero $(1.1 \%)$ for high accruals firms contradicting with $H 3 a$. The difference in correlation to return between low and high accruals firms is almost statistically significant ( $p=0.152)$. For actual taxable return $(A T I)$, the results give support to $H 3 b$, since its $R E P$ is for high accruals firms $89.7 \%$ being for low accruals firms only $40.9 \%$. The difference of the correlation of ATI to return between the groups is however not statistically significant $(p=$ 0.382).

For year 2013, the explanation power of PTBI is for both groups lower than for year 2012. For ETI, the power is negative for both low and high accruals firms so that the findings are inconclusive for $H 3 a$. For $A T I$, the power in year 2013 is about zero for low accruals firms but positive for high accruals firms supporting $H 3 b$. In year 2013, its $R E P$ for high accruals firms is $46.7 \%$ clearly exceeding that for low accruals firms $(-20.0 \%)$. The difference in its correlation to return between the accruals groups is statistically significant $(p=0.058)$ for year 2013 . 
Table 4. Relative information content of estimated and actual taxable income to book income for high and low accruals firms.

Panel 1. Low accrual firms.

\begin{tabular}{|c|c|c|c|c|c|c|c|c|c|c|}
\hline Year & $\begin{array}{l}\text { Number of } \\
\text { firms }\end{array}$ & $\begin{array}{l}\text { Coefficie } \\
\text { nt of of } \\
\Delta \text { PTBI§ }\end{array}$ & \begin{tabular}{|l} 
p-value \\
of \\
coefficie \\
$\mathrm{nt}$
\end{tabular} & $\begin{array}{l}\mathrm{R}^{2}(\Delta \mathrm{PTBI}) \\
\&\end{array}$ & $\begin{array}{l}\text { Coefficie } \\
\mathrm{nt} \quad \text { of } \\
\Delta \mathrm{ETI}\end{array}$ & $\begin{array}{l}p \text {-value of } \\
\text { coefficient }\end{array}$ & $\begin{array}{l}\mathrm{R}^{2}(\Delta \mathrm{ETI}) \\
\&\end{array}$ & $\begin{array}{l}\text { Coefficie } \\
\text { nt of } \\
\triangle A T I \S\end{array}$ & \begin{tabular}{|l|}
$p$-value \\
of \\
coefficie \\
nt
\end{tabular} & $\begin{array}{l}R^{2}(\Delta \mathrm{A} \\
\mathrm{TI}) \&\end{array}$ \\
\hline 2012 & 50 & 0,378 & 0,011 & 0,110 & 0,366 & 0,014 & 0,101 & 0,271 & 0,075 & 0,045 \\
\hline 2013 & 50 & 0,239 & 0,103 & 0,035 & 0,028 & 0,851 & $-0,020$ & $-0,123$ & 0,424 & $-0,007$ \\
\hline
\end{tabular}

Panel 2. High accural firms.

\begin{tabular}{|c|c|c|c|c|c|c|c|c|c|c|}
\hline Year & $\begin{array}{l}\text { Number of } \\
\text { firms }\end{array}$ & $\begin{array}{l}\text { Coefficie } \\
\mathrm{nt} \text { of } \\
\triangle \mathrm{PTBI}\end{array}$ & $\begin{array}{l}\text { p-value } \\
\text { of } \\
\text { coefficie } \\
\mathrm{nt}\end{array}$ & $\begin{array}{l}\mathrm{R}^{2}(\triangle \mathrm{PTBI}) \\
\&\end{array}$ & \begin{tabular}{|ll}
\multicolumn{2}{l}{ Coefficie } \\
$\mathrm{nt} \quad$ of \\
$\Delta \mathrm{ETI}$
\end{tabular} & $\begin{array}{l}p \text {-value of } \\
\text { coefficient }\end{array}$ & $\begin{array}{l}\mathrm{R}^{2}(\Delta \mathrm{ETI}) \\
\&\end{array}$ & \begin{tabular}{|l}
\multicolumn{2}{l}{ Coefficie } \\
$\mathrm{nt} \quad$ of \\
$\Delta \mathrm{ATI} \S$ \\
\end{tabular} & \begin{tabular}{|l}
-value \\
of \\
coefficie \\
nt \\
\end{tabular} & $\begin{array}{l}\mathrm{R}^{2}(\Delta \mathrm{A} \\
\mathrm{TI}) \& \\
\end{array}$ \\
\hline 2012 & 50 & 0,336 & 0,022 & 0,087 & 0,152 & 0,309 & 0,001 & 0,307 & 0,028 & 0,078 \\
\hline 2013 & 50 & 0,274 & 0,075 & 0,045 & 0,135 & 0,387 & $-0,005$ & 0,215 & 0,156 & 0,021 \\
\hline
\end{tabular}

Panel 3. Low accruals firms.

\begin{tabular}{|c|c|c|c|c|}
\hline Year & $\begin{array}{l}\text { Number of } \\
\text { firms }\end{array}$ & $\begin{array}{l}\mathrm{R}^{2}(\Delta \mathrm{ETI}) / \\
\mathrm{R}^{2}(\Delta \mathrm{PTBI} \\
1\end{array}$ & $\begin{array}{l}\mathrm{R}^{2}(\triangle \mathrm{ATI}) \\
/ \\
\mathrm{R}^{2}(\triangle \mathrm{PTBI} \\
)\end{array}$ & $\begin{array}{l}\mathrm{R}^{2}(\Delta \mathrm{ATI}) / \\
\mathrm{R}^{2}(\Delta \mathrm{ETII})\end{array}$ \\
\hline 2012 & 50 & 0,918 & 0,409 & 0,446 \\
\hline 2013 & 50 & $-0,571$ & $-0,200$ & 0,350 \\
\hline
\end{tabular}

Panel 4. High accruals firms.

\begin{tabular}{|c|r|r|r|r|}
\hline & & $R^{2}(\Delta \mathrm{ETI}) /$ & $\begin{array}{l}\mathrm{R}^{2}(\Delta \mathrm{ATI}) \\
/\end{array}$ & \\
Year & $\begin{array}{l}\text { Number of } \\
\text { firms }\end{array}$ & \multicolumn{2}{l}{$\begin{array}{l}\mathrm{R}^{2}(\Delta \mathrm{PTBI} \\
\mathrm{R}^{2}(\Delta \mathrm{PTBI} \\
\text { ) }\end{array}$} & $\begin{array}{l}\mathrm{R}^{2}(\Delta \mathrm{ATI}) / \\
\mathrm{R}^{2}(\Delta \mathrm{ETII})\end{array}$ \\
\hline 2012 & 50 & 0,011 & 0,897 & 78,000 \\
\hline 2013 & 50 & $-0,111$ & 0,467 & $-4,200$ \\
\hline
\end{tabular}

Legend

$\S=$ Coefficient from a regression of return (rank) on the change (rank) in pre-tax book income, estimated taxable income or actual taxable income (Equation 2).

$\&=$ Adjusted $\mathrm{R}^{2}$ from a regression of return (rank) on the change (rank) in pre-tax book income, estimated taxable income or actual taxable income (Equation 2).

$\triangle P T B I=$ Difference in $100 \cdot$ pre-tax book income deflated by market value.

$\triangle E T I=$ Difference in 100 . estimated taxable income deflated by market value.

$\triangle A T I=$ Difference in $100 \cdot$ actual taxable income deflated by market value.

\section{Incremental explanatory power}

Table 5 presents the incremental information content for the income concepts. The results indicate that estimated taxable income (ETI) does not contain any incremental explanation power to pre-tax book income (PTBI) in either year. For both years, IEP of ETI is negative and its coefficient in mutual regression with PTBI (Equation 4) is statistically insignificant contradicting with H1a. However, for year 2012 IEP of ATI is positive (2\%) and its regression coefficient is significant ( $p=0.078$ ) supporting H1b. For year 2013, ATI does not however contain any incremental explanation power to PTBI contradicting with $H 1 b$. For year 2012, ATI contains incremental information to ETI leading to positive IEP $(3.2 \%)$ and statistically significant regression coefficients. Thus, for that year, the findings contradict with $H 2 a$. For 2013, however, neither ETI nor ATI has a significant coefficient in mutual regression (Equation 4) and IEP is negative which does not contradict with the hypothesis but being merely inconclusive. 
Table 6 reports the results on incremental information for the non-zero tax firms. The findings show that neither ETI nor ATI includes any incremental information to PTBI in either year, since each IEP is negative. Thus, the results contradict with H1a and H1b. Similarly, ATI does not contain any incremental information to ETI conforming $H 2 a$. Thus, the incremental information contained by ATI to PTBI (in 2012) vanishes when only non-zero tax firms are considered.

\section{Table 5. Incremental information content of estimated and actual taxable income to book income for all sample firms.}

Panel 1. Incremental information of $\Delta \mathrm{ETI}$ over $\Delta \mathrm{PTBI}$.

\begin{tabular}{|c|c|c|c|c|c|c|c|c|c|}
\hline Year & $\begin{array}{l}\text { Numbe } \\
r \quad \text { of } \\
\text { firms }\end{array}$ & $\begin{array}{l}\text { Coefficient } \\
\text { of } \triangle \text { PTBI§ }\end{array}$ & $\begin{array}{l}p \text {-value of } \\
\text { coefficient }\end{array}$ & $\begin{array}{l}\mathrm{R}^{2}(\triangle \mathrm{PTBI}) \\
\&\end{array}$ & $\begin{array}{l}\text { Coefficient } \\
\text { of } \triangle \text { PTBI\# }\end{array}$ & $\begin{array}{l}p \text {-value of } \\
\text { coefficient }\end{array}$ & \begin{tabular}{|ll}
\multicolumn{2}{l}{ Coefficie } \\
$\mathrm{nt}$ & of \\
$\Delta \mathrm{ETI} \#$ & \\
\end{tabular} & $\begin{array}{l}p \text {-value } \\
\text { of } \\
\text { coefficie } \\
\text { nt }\end{array}$ & $\begin{array}{l}\mathrm{R}^{2}(\triangle \mathrm{PTBI}+ \\
\Delta \mathrm{ETI}) \&\end{array}$ \\
\hline 2012 & 100 & 0,353 & 0,000 & 0,111 & 0,318 & 0,010 & 0,050 & 0,625 & 0,105 \\
\hline 2013 & 100 & 0,256 & 0,012 & 0,053 & 0,252 & 0,018 & 0,014 & 0,892 & 0,043 \\
\hline
\end{tabular}

Panel 2. Incremental information of $\triangle \mathrm{ATI}$ over $\triangle \mathrm{PTBI}$.

\begin{tabular}{|c|c|c|c|c|c|c|c|c|c|}
\hline Year & $\begin{array}{l}\text { Numbe } \\
r \quad \text { of } \\
\text { firms }\end{array}$ & $\begin{array}{l}\text { Coefficient } \\
\text { of } \triangle \text { PTBI§ }\end{array}$ & $\begin{array}{l}\text { p-value of } \\
\text { coefficient }\end{array}$ & $\begin{array}{l}\mathrm{R}^{2}(\triangle \mathrm{PTBI}) \\
\&\end{array}$ & $\begin{array}{l}\text { Coefficient } \\
\text { of } \triangle \mathrm{PTBI \#}\end{array}$ & $\begin{array}{l}p \text {-value of } \\
\text { coefficient }\end{array}$ & \begin{tabular}{|ll}
\multicolumn{2}{l}{ Coefficie } \\
$\mathrm{nt}$ & of \\
$\Delta \mathrm{ATI} \#$
\end{tabular} & $\begin{array}{l}\text { p-value } \\
\text { of } \\
\text { coefficie } \\
\text { nt }\end{array}$ & $\begin{array}{l}\mathrm{R}^{2}(\triangle \mathrm{PTBI}+ \\
\triangle \mathrm{ATI}) \&\end{array}$ \\
\hline 2012 & 100 & 0,353 & 0,000 & 0,111 & 0,295 & 0,004 & 0,177 & 0,078 & 0,131 \\
\hline 2013 & 100 & 0,256 & 0,012 & 0,053 & 0,257 & 0,014 & $-0,006$ & 0,952 & 0,043 \\
\hline
\end{tabular}

Panel 3. Incremental information of $\triangle \mathrm{ATI}$ over $\Delta \mathrm{ETI}$.

\begin{tabular}{|c|c|c|c|c|c|c|c|c|c|}
\hline Year & $\begin{array}{l}\text { Numbe } \\
r \quad \text { of } \\
\text { firms }\end{array}$ & $\begin{array}{l}\text { Coefficient } \\
\text { of } \Delta \mathrm{ETI} \S\end{array}$ & $\begin{array}{l}p \text {-value of } \\
\text { coefficient }\end{array}$ & $\mathrm{R}^{2}(\Delta \mathrm{ETI}) \&$ & $\begin{array}{l}\text { Coefficient } \\
\text { of } \Delta \mathrm{ETI} \#\end{array}$ & $\begin{array}{l}p \text {-value of } \\
\text { coefficient }\end{array}$ & $\begin{array}{l}\text { Coefficie } \\
\mathrm{nt} \quad \text { of } \\
\Delta \mathrm{ATI} \#\end{array}$ & $\begin{array}{l}\text { p-value } \\
\text { of } \\
\text { coefficie } \\
\text { nt }\end{array}$ & $\begin{array}{l}\mathrm{R}^{2}(\Delta \mathrm{ETI}+ \\
\Delta \mathrm{ATI}) \&\end{array}$ \\
\hline 2012 & 100 & 0,250 & 0,014 & 0,051 & 0,182 & 0,082 & 0,215 & 0,037 & 0,083 \\
\hline 2013 & 100 & 0,083 & 0,425 & $-0,004$ & 0,077 & 0,466 & 0,035 & 0,745 & $-0,013$ \\
\hline
\end{tabular}

Panel 4. Summary measures of incremental

information.

\begin{tabular}{|c|c|c|c|c|}
\hline Year & $\begin{array}{l}\text { Numbe } \\
r \quad \text { of } \\
\text { firms }\end{array}$ & $\begin{array}{l}\mathrm{R}^{2}(\Delta \mathrm{PTBI}+ \\
\Delta \mathrm{ETI}) \\
\mathrm{R}^{2}(\Delta \mathrm{PTBI})\end{array}$ & $\begin{array}{l}\mathrm{R}^{2}(\triangle \mathrm{PTBI}+ \\
\Delta \mathrm{ATI}) \\
\mathrm{R}^{2}(\triangle \mathrm{PTBI})\end{array}$ & $\begin{array}{l}\mathrm{R}^{2}(\Delta \mathrm{ETI}+ \\
\Delta \mathrm{ATI}) \\
\mathrm{R}^{2}(\Delta \mathrm{ETI}) \\
\end{array}$ \\
\hline 2012 & 100 & $-0,006$ & 0,020 & 0,032 \\
\hline 2013 & 100 & $-0,010$ & $-0,010$ & $-0,009$ \\
\hline
\end{tabular}

Legend

$\S=$ Coefficient from a regression of return (rank) on the change (rank) in pre-tax book income, estimated taxable income or actual taxable income (Equation 4).

\# = Coefficient from a regression of return (rank) on the change (rank) in pre-tax book income and estimated taxable income or actual taxable income (Equation 4).

$\&=$ Adjusted $R^{2}$ from a regression of return (rank) on the change (rank) in pre-tax book income, estimated taxable income and/or actual taxable income (Equation 4).

$\triangle P T B I=$ Difference in $100 \cdot$ pre-tax book income deflated by market value.

$\triangle E T I=$ Difference in $100 \cdot$ estimated taxable income deflated by market value.

$\triangle A T I=$ Difference in $100 \cdot$ actual taxable income deflated by market value. 
Table 6. Incremental information content of estimated and actual taxable income to book income for non-zero tax firms.

Panel 1. Incremental information of $\triangle \mathrm{ETI}$ over $\triangle \mathrm{PTBI}$.

\begin{tabular}{|c|c|c|c|c|c|c|c|c|c|}
\hline Year & $\begin{array}{l}\text { Numbe } \\
r \quad \text { of } \\
\text { firms }\end{array}$ & $\begin{array}{l}\text { Coefficient } \\
\text { of } \triangle \text { PTBI§ }\end{array}$ & $\begin{array}{l}\mathrm{p} \text {-value of } \\
\text { coefficient }\end{array}$ & $\mathrm{R}^{2}(\triangle \mathrm{PTBI}) \&$ & $\begin{array}{l}\text { Coefficien } \\
t \quad \text { of } \\
\triangle \text { PTBI\# }\end{array}$ & $\begin{array}{l}p \text {-value of } \\
\text { coefficient }\end{array}$ & $\begin{array}{l}\text { Coefficien } \\
\mathrm{t} \text { of } \Delta \mathrm{ETI} \#\end{array}$ & $\begin{array}{l}p \text {-value of } \\
\text { coefficien } \\
t\end{array}$ & $\begin{array}{l}\mathrm{R}^{2}(\Delta \mathrm{PTBI}+ \\
\Delta \mathrm{ETI}) \&\end{array}$ \\
\hline 2012 & 56 & 0,476 & 0,000 & 0,201 & 0,407 & 0,017 & 0,106 & 0,524 & 0,192 \\
\hline 2013 & 54 & 0,117 & 0,412 & $-0,006$ & 0,111 & 0,517 & 0,011 & 0,951 & $-0,026$ \\
\hline
\end{tabular}

Panel 2. Incremental information of $\triangle \mathrm{ATI}$ over $\triangle \mathrm{PTBI}$.

\begin{tabular}{|c|c|c|c|c|c|c|c|c|c|}
\hline Year & \begin{tabular}{|l|}
\multicolumn{2}{l}{ Numbe } \\
$r \quad$ of \\
firms
\end{tabular} & $\begin{array}{l}\text { Coefficient } \\
\text { of } \triangle \text { PTBI§ }\end{array}$ & $\begin{array}{l}p \text {-value of } \\
\text { coefficient }\end{array}$ & $\mathrm{R}^{2}(\Delta \mathrm{PTBI}) \&$ & $\begin{array}{l}\text { Coefficien } \\
\mathrm{t} \text { of } \\
\Delta \text { PTBI\# }\end{array}$ & $\begin{array}{l}p \text {-value of } \\
\text { coefficient }\end{array}$ & $\begin{array}{l}\text { Coefficien } \\
t \text { of } \triangle A T I \#\end{array}$ & $\begin{array}{l}p \text {-value of } \\
\text { coefficien } \\
t\end{array}$ & $\begin{array}{l}\mathrm{R}^{2}(\triangle \mathrm{PTBI}+ \\
\triangle \mathrm{ATI}) \&\end{array}$ \\
\hline 2012 & 56 & 0,476 & 0,000 & 0,201 & 0,440 & 0,002 & 0,107 & 0,423 & 0,196 \\
\hline 2013 & 54 & 0,117 & 0,412 & $-0,006$ & 0,137 & 0,371 & $-0,059$ & 0,698 & $-0,023$ \\
\hline
\end{tabular}

Panel 3. Incremental information of $\triangle \mathrm{ATI}$ over $\Delta \mathrm{ETI}$.

\begin{tabular}{|r|r|r|r|r|r|r|r|r|r|}
\hline Year & $\begin{array}{l}\text { Numbe } \\
\text { firms of }\end{array}$ & $\begin{array}{l}\text { Coefficient } \\
\text { of } \Delta \mathrm{ETI}\end{array}$ & $\begin{array}{l}\text { p-value of } \\
\text { coefficient }\end{array}$ & $\mathrm{R}^{2}(\Delta \mathrm{ETI}) \&$ & $\begin{array}{l}\text { Coefficien } \\
\mathrm{t} \text { of } \Delta \mathrm{ETI} \#\end{array}$ & $\begin{array}{l}\mathrm{p} \text {-value of } \\
\text { coefficient }\end{array}$ & $\begin{array}{l}\text { Coefficien } \\
\mathrm{t} \text { of } \Delta \mathrm{ATI}\end{array}$ & $\begin{array}{l}\mathrm{p} \text {-value of } \\
\text { coefficien } \\
\mathrm{t}\end{array}$ & $\begin{array}{l}\mathrm{R}^{2}(\Delta \mathrm{ETI}+ \\
\Delta \mathrm{ATI}) \&\end{array}$ \\
\hline 2012 & 56 & 0,374 & 0,006 & 0,116 & 0,322 & 0,028 & 0,126 & 0,883 & 0,113 \\
\hline 2013 & 54 & 0,071 & 0,618 & $-0,014$ & 0,088 & 0,572 & $-0,045$ & 0,792 & $-0,033$ \\
\hline
\end{tabular}

Panel 4. Summary measures of incremental information.

\begin{tabular}{|c|r|r|r|lr|}
\hline & \multicolumn{2}{|l|}{ Numbe } & $R^{2}(\Delta \mathrm{PTBI}+$ & $R^{2}(\Delta \mathrm{PTBI}+$ & $\mathrm{R}^{2}(\Delta \mathrm{ETI}+$ \\
Year & $\begin{array}{l}\text { r of } \\
\text { firms }\end{array}$ & $\begin{array}{l}\Delta \mathrm{ETI}) \\
\mathrm{R}^{2}(\Delta \mathrm{PTBI})\end{array}$ & $\begin{array}{l}\Delta \mathrm{ATI}) \\
\mathrm{R}^{2}(\Delta \mathrm{PTBI})\end{array}$ & $\begin{array}{l}\Delta \mathrm{ATI}) \\
\mathrm{R}^{2}(\Delta \mathrm{ETI})\end{array}$ \\
\hline 2012 & 56 & $-0,009$ & $-0,005$ & $-0,003$ \\
\hline 2013 & 54 & $-0,020$ & $-0,017$ & $-0,019$ \\
\hline
\end{tabular}

Legend

$\S=$ Coefficient from a regression of return (rank) on the change (rank) in pre-tax book income, estimated taxable income or actual taxable income (Equation 4).

\# = Coefficient from a regression of return (rank) on the change (rank) in pre-tax book income and estimated taxable income or actual taxable income (Equation 4).

$\&=$ Adjusted $R^{2}$ from a regression of return (rank) on the change (rank) in pre-tax book income, estimated taxable income and/or actual taxable income (Equation 4).

$\triangle P T B I=$ Difference in $100 \cdot$ pre-tax book income deflated by market value .

$\triangle E T I=$ Difference in $100 \cdot$ estimated taxable income deflated by market value.

$\triangle A T I=$ Difference in $100 \cdot$ actual taxable income deflated by market value.

Table 7 presents the findings on the incremental information for the low accruals (high quality earnings information) firms whereas Table 8 reports the results for the high accruals (low quality earnings information) firms. Table 7 shows that neither ETI nor ATI includes incremental information to book income (PTBI) in both years. Although IEP is positive (1.1\%) for ETI, its regression coefficient is not statistically significant $(p=0.209)$ in mutual regression (Equation 4). Furthermore, ATI does not include incremental information to ETI. Table 8 indicates that ETI does not contain any incremental information to PTBI in either year which does not support H4a. However, IEP of ATI on PTBI is positive for both years and for year 2012 its regression coefficient is significant ( $p=0.081$ ). Thus, these findings give support to $H 4 b$. Furthermore, IEPs of ATI on ETI are positive in both years and the regression coefficient of ATI is significant especially in year 2012 (o = 0.043). Therefore, empirical evidence contradicts with $H 4 c$. 


\section{Table 7. Incremental information content of estimated and actual taxable income to book income for low accruals}

Panel 1. Incremental information of $\Delta \mathrm{ETI}$ over $\Delta \mathrm{PTBI}$.

\begin{tabular}{|c|c|c|c|c|c|c|c|c|c|}
\hline Year & $\begin{array}{l}\text { Numbe } \\
r \quad \text { of } \\
\text { firms }\end{array}$ & $\begin{array}{l}\text { Coefficient } \\
\text { of } \triangle \text { PTBI§ }\end{array}$ & $\begin{array}{l}p \text {-value of } \\
\text { coefficient }\end{array}$ & $\mathrm{R}^{2}(\triangle \mathrm{PTBI}) \&$ & $\begin{array}{l}\text { Coefficien } \\
\mathrm{t} \text { of } \\
\triangle \mathrm{PTBI} \#\end{array}$ & $\begin{array}{l}p \text {-value of } \\
\text { coefficient }\end{array}$ & $\begin{array}{l}\text { Coefficien } \\
\mathrm{t} \text { of } \Delta \mathrm{ETI} \#\end{array}$ & $\begin{array}{l}p \text {-value of } \\
\text { coefficien } \\
t\end{array}$ & $\begin{array}{l}\mathrm{R}^{2}(\Delta \mathrm{PTBI}+ \\
\Delta \mathrm{ETI}) \&\end{array}$ \\
\hline 2012 & 50 & 0,378 & 0,011 & 0,110 & 0,250 & 0,157 & 0,221 & 0,209 & 0,121 \\
\hline 2013 & 50 & 0,239 & 0,103 & 0,035 & 0,247 & 0,106 & $-0,032$ & 0,834 & 0,015 \\
\hline
\end{tabular}

Panel 2. Incremental information of $\triangle \mathrm{ATI}$ over $\triangle \mathrm{PTBI}$.

\begin{tabular}{|c|c|c|c|c|c|c|c|c|c|}
\hline Year & $\begin{array}{l}\text { Numbe } \\
r \quad \text { of } \\
\text { firms }\end{array}$ & $\begin{array}{l}\text { Coefficient } \\
\text { of } \triangle \text { PTBI§ }\end{array}$ & $\begin{array}{l}p \text {-value of } \\
\text { coefficient }\end{array}$ & $\mathrm{R}^{2}(\triangle \mathrm{PTBI}) \&$ & $\begin{array}{l}\text { Coefficien } \\
t \quad \text { of } \\
\Delta \text { PTBI\# }\end{array}$ & $\begin{array}{l}\text { p-value of } \\
\text { coefficient }\end{array}$ & $\begin{array}{l}\text { Coefficien } \\
t \text { of } \triangle A T I \#\end{array}$ & $\begin{array}{l}\text { p-value of } \\
\text { coefficien } \\
t\end{array}$ & $\begin{array}{l}\mathrm{R}^{2}(\triangle \mathrm{PTBI}+ \\
\Delta \mathrm{ATI}) \& \\
\end{array}$ \\
\hline 2012 & 50 & 0,378 & 0,011 & 0,110 & 0,323 & 0,043 & 0,144 & 0,363 & 0,107 \\
\hline 2013 & 50 & 0,239 & 0,103 & 0,035 & 0,279 & 0,064 & $-0,185$ & 0,228 & 0,044 \\
\hline
\end{tabular}

Panel 3. Incremental information of $\triangle \mathrm{ATI}$ over $\Delta \mathrm{ETI}$.

\begin{tabular}{|c|c|c|c|c|c|c|c|c|c|}
\hline Year & $\begin{array}{l}\text { Numbe } \\
r \quad \text { of } \\
\text { firms }\end{array}$ & $\begin{array}{l}\text { Coefficient } \\
\text { of } \Delta \mathrm{ETI} \S\end{array}$ & $\begin{array}{l}\mathrm{p} \text {-value of } \\
\text { coefficient }\end{array}$ & $\mathrm{R}^{2}(\Delta \mathrm{ETI}) \&$ & $\begin{array}{l}\text { Coefficien } \\
t \text { of } \Delta E T I \#\end{array}$ & $\begin{array}{l}\text { p-value of } \\
\text { coefficient }\end{array}$ & $\begin{array}{l}\text { Coefficien } \\
t \text { of } \triangle A T I \#\end{array}$ & $\begin{array}{l}\text { p-value of } \\
\text { coefficien } \\
t\end{array}$ & $\begin{array}{l}\mathrm{R}^{2}(\Delta \mathrm{ETI}+ \\
\Delta \mathrm{ATI}) \&\end{array}$ \\
\hline 2012 & 50 & 0,366 & 0,014 & 0,101 & 0,368 & 0,056 & 0,146 & 0,364 & 0,098 \\
\hline 2013 & 50 & 0,028 & 0,851 & $-0,020$ & 0,076 & 0,633 & $-0,148$ & 0,366 & $-0,024$ \\
\hline
\end{tabular}

Panel 4. Summary measures of incremental information.

\begin{tabular}{|c|c|c|c|c|}
\hline Year & $\begin{array}{l}\text { Numbe } \\
r \quad \text { of } \\
\text { firms }\end{array}$ & $\begin{array}{l}\mathrm{R}^{2}(\Delta \mathrm{PTBI}+ \\
\Delta \mathrm{ETI}) \\
\mathrm{R}^{2}(\Delta \mathrm{PTBI})\end{array}$ & $\begin{array}{l}\mathrm{R}^{2}(\Delta \mathrm{PTBI}+ \\
\Delta \mathrm{ATI}) \\
\mathrm{R}^{2}(\Delta \mathrm{PTBI})\end{array}$ & $\begin{array}{l}\mathrm{R}^{2}(\Delta \mathrm{ETI}+ \\
\Delta \mathrm{ATI}) \\
\mathrm{R}^{2}(\Delta \mathrm{ETI})\end{array}$ \\
\hline 2012 & 50 & 0,011 & $-0,003$ & $-0,003$ \\
\hline 2013 & 50 & $-0,020$ & 0,009 & $-0,004$ \\
\hline
\end{tabular}

Legend

:

$\S=$ Coefficient from a regression of return (rank) on the change (rank) in pre-tax book income, estimated taxable income or actual taxable income (Equation 4).

\# = Coefficient from a regression of return (rank) on the change (rank) in pre-tax book income and estimated taxable income or actual taxable income (Equation 4).

$\&=$ Adjusted $\mathrm{R}^{2}$ from a regression of return (rank) on the change (rank) in pre-tax book income, estimated taxable income and/or actual taxable income (Equation ).

$\triangle P T B I=$ Difference in $100 \cdot$ pre-tax book income deflated by market value.

$\triangle E T I=$ Difference in $100 \cdot$ estimated taxable income deflated by market value .

$\triangle A T I=$ Difference in $100 \cdot$ actual taxable income deflated by market value. 
Table 8. Incremental information content of estimated and actual taxable income to book income for high accruals firms

Panel 1. Incremental information of $\triangle E T I$ over $\triangle$ PTBI.

\begin{tabular}{|c|c|c|c|c|c|c|c|c|c|}
\hline Year & $\begin{array}{l}\text { Numbe } \\
r \quad \text { of } \\
\text { firms }\end{array}$ & $\begin{array}{l}\text { Coefficient } \\
\text { of } \triangle \text { PTBI§ }\end{array}$ & $\begin{array}{l}p \text {-value of } \\
\text { coefficient }\end{array}$ & $\mathrm{R}^{2}(\triangle \mathrm{PTBI}) \&$ & $\begin{array}{l}\text { Coefficien } \\
t \quad \text { of } \\
\triangle \text { PTBI\# }\end{array}$ & $\begin{array}{l}p \text {-value of } \\
\text { coefficient }\end{array}$ & $\begin{array}{l}\text { Coefficien } \\
\mathrm{t} \text { of } \Delta \mathrm{ETI} \#\end{array}$ & $\begin{array}{l}p \text {-value of } \\
\text { coefficien } \\
t\end{array}$ & $\begin{array}{l}\mathrm{R}^{2}(\Delta \mathrm{PTBI}+ \\
\Delta \mathrm{ETI}) \&\end{array}$ \\
\hline 2012 & 50 & 0,336 & 0,022 & 0,087 & 0,378 & 0,038 & 0,072 & 0,688 & 0,070 \\
\hline 2013 & 50 & 0,274 & 0,075 & 0,045 & 0,257 & 0,112 & 0,061 & 0,702 & 0,028 \\
\hline
\end{tabular}

Panel 2. Incremental information of $\triangle \mathrm{ATI}$ over $\triangle \mathrm{PTBI}$.

\begin{tabular}{|c|c|c|c|c|c|c|c|c|c|}
\hline Year & $\begin{array}{l}\text { Numbe } \\
r \quad \text { of } \\
\text { firms }\end{array}$ & $\begin{array}{l}\text { Coefficient } \\
\text { of } \triangle \text { PTBI§ }\end{array}$ & $\begin{array}{l}p \text {-value of } \\
\text { coefficient }\end{array}$ & $\mathrm{R}^{2}(\triangle \mathrm{PTBI}) \&$ & $\begin{array}{l}\text { Coefficien } \\
\mathrm{t} \quad \text { of } \\
\Delta \text { PTBI\# }\end{array}$ & $\begin{array}{l}p \text {-value of } \\
\text { coefficient }\end{array}$ & $\begin{array}{l}\text { Coefficien } \\
t \text { of } \Delta \mathrm{ATI} \#\end{array}$ & $\begin{array}{l}p \text {-value of } \\
\text { coefficien } \\
t\end{array}$ & $\begin{array}{l}\mathrm{R}^{2}(\triangle \mathrm{PTBI}+ \\
\triangle \mathrm{ATI}) \&\end{array}$ \\
\hline 2012 & 50 & 0,336 & 0,022 & 0,087 & 0,272 & 0,062 & 0,242 & 0,081 & 0,126 \\
\hline 2013 & 50 & 0,274 & 0,075 & 0,045 & 0,239 & 0,126 & 0,166 & 0,274 & 0,050 \\
\hline
\end{tabular}

Panel 3. Incremental information of $\triangle \mathrm{ATI}$ over $\Delta \mathrm{ETI}$.

\begin{tabular}{|r|r|r|r|r|r|r|r|r|r|}
\hline Year & $\begin{array}{l}\text { Numbe } \\
\text { firms of }\end{array}$ & $\begin{array}{l}\text { Coefficient } \\
\text { of } \Delta \mathrm{ETI}\end{array}$ & $\begin{array}{l}\text { p-value of } \\
\text { coefficient }\end{array}$ & $R^{2}(\Delta \mathrm{ETI}) \&$ & $\begin{array}{l}\text { Coefficien } \\
\mathrm{t} \text { of } \Delta \mathrm{ETI} \#\end{array}$ & $\begin{array}{l}\mathrm{p} \text {-value of } \\
\text { coefficient }\end{array}$ & $\begin{array}{l}\text { Coefficien } \\
\mathrm{t} \text { of } \Delta \mathrm{ATI \#}\end{array}$ & $\begin{array}{l}\mathrm{p} \text {-value of } \\
\text { coefficien } \\
\mathrm{t}\end{array}$ & $\begin{array}{l}\mathrm{R}^{2}(\Delta \mathrm{ETI}+ \\
\Delta \mathrm{ATI}) \&\end{array}$ \\
\hline 2012 & 50 & 0,152 & 0,309 & 0,001 & 0,089 & 0,546 & 0,289 & 0,043 & 0,066 \\
\hline 2013 & 50 & 0,135 & 0,387 & $-0,005$ & 0,128 & 0,407 & 0,211 & 0,166 & 0,015 \\
\hline
\end{tabular}

Panel 4. Summary measures of incremental information.

\begin{tabular}{|c|c|c|c|c|}
\hline Year & $\begin{array}{l}\text { Numbe } \\
r \quad \text { of } \\
\text { firms }\end{array}$ & $\begin{array}{ll}\mathrm{R}^{2}(\Delta \mathrm{PTBI}+ \\
\Delta \mathrm{ETI}) \\
\mathrm{R}^{2}(\Delta \mathrm{PTBI})\end{array}$ & $\begin{array}{l}\mathrm{R}^{2}(\triangle \mathrm{PTBI}+ \\
\Delta \mathrm{ATI}) \\
\mathrm{R}^{2}(\Delta \mathrm{PTBI}) \\
\end{array}$ & $\begin{array}{l}\mathrm{R}^{2}(\Delta \mathrm{ETI}+ \\
\Delta \mathrm{ATI}) \\
\mathrm{R}^{2}(\Delta \mathrm{ETI})\end{array}$ \\
\hline 2012 & 50 & $-0,017$ & 0,039 & 0,065 \\
\hline 2013 & 50 & $-0,017$ & 0,005 & 0,020 \\
\hline
\end{tabular}

Legend

:

$\S=$ Coefficient from a regression of return (rank) on the change (rank) in pre-tax book income, estimated taxable income or actual taxable income (Equation 4).

\# = Coefficient from a regression of return (rank) on the change (rank) in pre-tax book income and estimated taxable income or actual taxable income (Equation 4).

$\&=$ Adjusted $R^{2}$ from a regression of return (rank) on the change (rank) in pre-tax book income, estimated taxable income and/or actual taxable income (Equation 4).

$\triangle P T B I=$ Difference in $100 \cdot$ pre-tax book income deflated by market value.

$\triangle E T I=$ Difference in $100 \cdot$ estimated taxable income deflated by market value.

$\triangle A T I=$ Difference in $100 \cdot$ actual taxable income deflated by market value.

\section{CONCLUDING DISCUSSION}

There are several empirical studies indicating that book-tax differences are useful measures in evaluating firm performance (Hanlon, 2005; Lev \& Nissim, 2004; Ayers, Jiang \& Laplante, 2009). Many studies concentrate on the comparison of the information content of book income and taxable income to stock returns which is an important question to stakeholders. Shevlin (2002) and Hanlon, Laplante \& Shevlin (2005) conclude that book income explains annual stock returns better than estimated taxable income that is calculated using financial statement disclosures. However, they also report that this estimated taxable income brings incremental explanatory power to book income indicating that taxable income summarizes information reflected in stock returns that is not captured by book income. The present study contributes to this discussion assessing the information content of both estimated and actual taxable income using Finnish corporate data from 2012-2013. However, only mainly the findings from year 2012 are considered below. The findings are consistent with Shevlin (2002) and Hanlon, 
Laplante \& Shevlin (2005) in that book income has higher explanation power of stock returns than other income concepts. However, estimated taxable income does not bring any incremental explanatory power to book income whereas actual taxable income contains more relative information and also incremental information power to explain returns.

Ayers, Jiang \& Laplante (2009) report that the relative and incremental information content of estimated taxable income to book income is higher for low earnings quality firms. However, the present study indicates that in low accruals firms (high earnings quality) the explanation power of estimated taxable income is comparable with that of book income. In the high accruals firms (low earnings quality) this power is insignificant. The explanation power of actual taxable income is lower for low accruals firms and higher for high accruals firms being comparable with that of book income. Its relative explanatory power is only less than half of that for estimated taxable income in low accruals firms. Thus, empirical evidence on relative information content is not consistent with Ayers, Jiang \& Laplante (2009) when estimated taxable income is considered. For low accruals firms, neither of the taxable income concepts brings incremental information to book income. For high accruals firms, estimated taxable income does not bring any incremental information to book income whereas actual taxable income does. Thus, estimated taxable income does not enhance information content when earnings quality is lower. For high accrual firms, actual taxable income brings significant incremental information also to estimated taxable income.

The robustness of findings was assessed in many ways. Because of the unstable economic development in Finland during the research period the regression equations of return were estimated using the ranks of variables to control for extreme values of variables and for changes in market volatility (Ali \& Whang, 2000). For regressions with original variables (without rank transformation), the explanatory power of variables was similar but significantly lower. In this study, a 23-month window was used in estimation since actual corporate tax information is released not before next November, almost eleven months after the year-end. When a 16-month window (typical for research on financial statement information releases) was used, the results were as expected. The explanatory power of book income was very strong for both year 2012 and 2013. However, the explanatory power of estimated taxable income was higher than for longer window in year 2012 but about zero in year 2013. Furthermore, actual taxable income consistently did not contain any explanatory power for such a short window ending before tax releases.

The most findings of the study for year 2013 are against expectations due to the very low or negligible explanatory power of taxable income concepts. Thus, something has happened in the stock markets in period 2013-2014 which had a strong influence on the relationship between stock returns and income concepts. In year 2012, the change in Helsinki all-share index was $8.3 \%$ but in year $201326.5 \%$ falling back in the next year (5.7\%). In the same time, turnover rate decreased from 80.8 to 66.6. Furthermore, in autumn 2013 (September 16th) the Finnish government released the first version of the next year budget where the corporate tax rate was decreased from 0.245 in 2012-2013 to 0.20 in 2014. This information was fully known to market participants in 2013 which should have affected tax planning behavior in that year. Many empirical studies indicate that this kind of anticipated tax rate reduction provides incentives to manage both book income and taxable income downward (Roubi \& Richardson, 1998; Lin, 2006; Wong, Lo \& Firth, 2015). The effect of tax rate reduction is quite strong also for reported income in year 2014. Some researchers present as the semi-elasticity of the corporate tax base for reported profit shifting -0.6 (Huizinga \& Leaven, 2008) or even -1.2 (de Mooij \& Everdeen, 2008). Before ending of the 23-month window, three quarterly financial 
reports for year 2014 have already been released when actual tax information for year 2013 is disclosed.

In summary, the present study shows that actual taxable income brings incremental information to book income in explaining stock returns The explanation power of actual taxable income is higher for high accruals firms reflected by low earnings quality. Corporate tax information is nowadays public only in a couple of countries such as Finland although it would be important for stakeholders of the firm. Therefore, empirical evidence indicates that it would be recommendable to make it public also in other countries. In Finland, taxation information is released not until 10-11 months after the year-end. Thus, even if bringing still incremental information, it is quite old considerably diminishing the value of information. Therefore, it would be recommendable to expedite the time table of releasing tax information. The study also shows that anticipated tax reduction can due to earnings management strongly distort the detection of relevant relationships between returns and income concepts. Therefore, in tax research the forthcoming tax rate changes should be carefully taken into account when interpreting the results

\section{References}

Ali, A. \&Hwang, L.S. (2000). Country-specific factors related to financial reporting and the value relevance of accounting data. Journal of Accounting Research. 38(1): 1-21.

Ayers, B., Jiang, X. \& Laplante, S. (2009). Taxable income as a performance measure: the effects of tax planning and earnings quality. Contemporary Accounting Research. 26(1): 15-54.

Biddle, G.C., Seow, G.S. \& Siegel, A.F. (1995). Relative Versus Incremental Information Content. Contemporary Accounting Research. 12(1): 1-23.

Cohen, J. \& Cohen, P. (1983). Applied multiple regression/correlation analysis for the behavioral sciences. Hillsdale, NJ: Erlbaum.

de Mooij, R.A. \& Everdeen, S. (2008) Corporate tax elasticities: a reader's guide to empirical findings. Oxford review of economic policy. 24(4): 680-697.

Dechow, P., Ge, W. \& Schrand, C. (2010). Understanding earnings quality: A review of the proxies, their determinants and their consequences. Journal of Accounting and Economics. 50(2-3): 344-401.

Desai, M. (2006). Testimony of Mihir Desai (Associate Professor of Harvard University) before the Subcommittee on Select Revenue Measures. Committee on Ways and Means, House of Representatives, May 9.

Hanlon, M. (2003). What can we infer about a firm's taxable income from its financial statements? National Tax Journal 56(4): $831-63$.

Hanlon, M. (2005). The persistence and pricing of earnings, accruals and cash flows when firms have large booktax differences. The Accounting Review. 80(I): 137-66.

Hanlon, M. \& Heitzman, S. (2010). A review of tax research. Journal of Accounting and Economics 50(2-3): 127178.

Hanlon, M., Laplante, S.K. \& Shevlin, T. (2005). Evidence for the possible information loss of conforming book income and taxable income. Journal of Law and Economics. 48(2): 407-442.

Hanlon, M. \& Shevlin, T. (2003). Book-tax conformity for corporate income: An introduction to the issues. NBER working paper no. 11067. Cambridge, MA: National Bureau for Economic Research.

Huizinga, H. \& Laeven, L. (2008). International profit shifting within multinations: A multi-country perspective. Journal of Public Economics, 92(5-6): 1164-1182.

Kothari. S. P. (2001). Capital markets research in accounting. Journal of Accounting and Economics. 31(1-3): 105231.

Lev, B. \& Nissim, D. (2004). Taxable income, future earnings and equity values. The Accounting Review. 79(4): 1039-1074.

Lin, K. Z. (2006). The impact of tax holidays on earnings management: An empirical study of corporate reporting behavior in a developing economy framework. The International Journal of Accounting. 41(2):163-175. 
Mills, L. \& Plesko, G. (2003). Bridging the reporting gap: A proposal for more informative reconciling of book and tax income. National Tax Journal. 56(4): 865-93.

Phillips, J., Pincus, M. \& Rego, S.O. (2003). Earnings management: New evidence based on deferred tax expense. The Accounting Review. 78(2): 491-521.

Plesko, G. (2000). Book-tax differences and the measurement of corporate income. NTA Proceedings 1999. 171176. Washington, DC: National Tax Association.

Plesko, G. (2006). Estimates of the magnitude of financial and tax reporting conflicts. Working paper. University of Connecticut.

Revsine, L., Collins, D. \& Johnson, B. (2002). Financial reporting and analysis. Upper Saddle River, NJ: Prentice Hall. Roubi, R. \& Richardson, A. (1998). Managing discretionary accruals in response to reductions in corporate tax rates in Canada, Malaysia and Singapore. The International Journal of Accounting 33 (4): 455-467.

Shevlin, T. (2002). Commentary on corporate tax shelters and book-tax differences. Tax Law Review. 55(3): 42743.

Williams, E. J. (1959). The comparison of regression variables. Journal of the Royal Statistical Society (Series B). 21(2): 396-399.

Wong, R.M.K., Lo, A.W. \& Firth, M. (2015). Managing Discretionary Accruals and Book-Tax Differences in Anticipation of Tax Rate Increases: Evidence from China. Journal of International Financial Management \& Accounting. 26(2): 188-222. 